Bull.Fac, Agric.,Cairo Univ.,62: 204-212 (2011).

\title{
INFLUENCE OF DIFFERENT GROWING MEDIA ON GROWTH AND CHEMICAL CONSTITUENTS OF Schefflera arboricola.
}

\author{
(Received: 5. 1. 2011)
}

\author{
By \\ E. I. El-Maadawy, A. A. Nasr, A. A. M. Mazher* and S. M. El-Sayed * \\ Ornamental Horticulture Department, Faculty. of Agriculture, Cairo University, Giza, Egypt. \\ * Ornamental Plants and Woody Trees Department, National Research Centre, El-Dokki, Giza, Egypt
}

\begin{abstract}
The effect of different growing media on the growth and chemical constituents of Schefflera arboricola plants was studied in 2007 and 2008 in the greenhouse of the Research and Production Station, Nubaria. The results showed that using the mixture of peatmoss + clay (2:1) and peatmoss+ sand+ clay $(2: 1: 1)$ had a favorable effect on increasing all the growth parameters (plant height, stem diameter, number of leaves, leaf area, fresh and dry weights of leaves, stems and roots) as well as the content of pigments, total carbohydrates and nutrients (nitrogen, phosphorus and potassium) comparing with other growing media. Growing plants in mixtures of peatmoss + sand (1:1) or peatmoss + sand (2:1) reduced all the previous parameters, in both seasons, to the minimum values.
\end{abstract}

Key words: chemical constituents, clay, growing media, peatmoss, plant growth, sand, Schefflera arboricola.

\section{INTRODUCTION}

Schefflera arboricola is a member of the family Araliaceae, native to Taiwan and Hanian. It also goes by the common name "Dwarf umbrella tree". It is an evergreen shrub growing to $3-4 \mathrm{~m}$ height. It is commonly grown as a popular houseplant for its tolerance of neglect and poor growing conditions.

Growing media have several important functions in relation to plant growth. They act as a plant support, serve as a source of water and essential plant nutrients and permit the diffusion of oxygen to roots to satisfy the basic plant requirements.

El-Afghany (1981) found that sandy soil gave the least plant height of Eucalyptus camaldulensis, compared to the mixture of sand : peatmoss (3:1) which increased growth parameters. El-Tantawy (1981) reported that clay soil improved the vegetative growth of Casuarina equistifolia and Cupressus sempervirens, compared to sandy soil. Also, the mixture of clay and sand (1:1 v/v) gave satisfactory results. But, El-Fouly (1994) stated that peatmoss alone was most favorable medium for increasing the Scindapsus aureus plant height and dry weight.

El-Shoura and Hosni (1996) grew Sterlitzia reginea in pots containing $3: 1,1: 1,1: 3$ sand : clay or clay. Their results reflected that the plants grown in 1:3 sand : clay medium had the greatest number of leaves/ plant, long leaves and the highest leaf percentage dry weight.

Saleh (2001) on Cycas revolute, stated that using peatmoss or clay media gave the best results of vegetative growth ( plant height, leaf number/ plant and root length/ plant compared with the other planting media used (sand, sand : peat 1:1, sand +peat +clay 1:1:1 and clay :sand 1:1). Osman (2002) mentioned that growing Nerium oleander plants in clay increased plant height, whereas, using mixture of clay + sand + peat increased the number of branches and decreased stem diameter and root length.

The objective of this study was to investigate the effect of different growing media on the growth and the chemical composition of Schefflera arboricola plants.

\section{MATERIALS AND METHODS}

The experiments of this study were carried out in the greenhouse of the Research and Production Station, Nubaria during two successive years; 2007 and 2008.

\subsection{Plant material}

Uniformed young plants of Schefflera arboricola (4-6 leaves and $15-20 \mathrm{~cm}$ height) were used. The plants were obtained from the Research and Production Station, Nubaria . 
The young plants were transplanted individually on March, $10^{\text {th }} 2007$ and 2008 in 30 $\mathrm{cm}$ plastic pots, filled with one of the following media: Peatmoss - Peatmoss + sand (1:1) Peatmoss + sand (2:1) - Peatmoss + clay (1:1) Peatmoss + clay $(2: 1)$ - Peatmoss +sand + clay (1: $1: 1)$ - Peatmoss + sand+ clay (2:1:1).

The components of each medium were carefully mixed before transplanting. All the plants were held under the greenhouse conditions for 8 months continuously.

The physical and chemical properties of the different media are shown in Tables (A), (B) and (C). followed by Dubois et al., (1956). Chlorophyll ( $\mathrm{a}, \mathrm{b}$ and carotenoids mg / gm F.W.) contents in leaves were determined according to Saric et al., (1967). Nitrogen, phosphorus and potassium contents were determined according to the method described by Cottenie et al. (1982). The physical and chemical properties of the soil were determined according to Chapman and Pratt (1961).

Data were analyzed statistically according to Snedecor and Cochran (1980). The least significant difference (L.S.D.) at $5 \%$ for each character was calculated

Table (A): Physical properties of clay and sand of the different media.

\begin{tabular}{|l|c|c|c|c|}
\hline \multicolumn{1}{|c|}{ Soil sample } & Coarse sand\% & Find sand\% & Silt\% & Clay \% \\
\hline Clay & 25.0 & 15.0 & 14.0 & 46.0 \\
\hline Sand & 71.0 & 18.0 & 4.5 & 6.5 \\
\hline
\end{tabular}

Table (B): Chemical analysis of clay and sand.

\begin{tabular}{|c|c|c|c|c|c|c|c|c|c|c|}
\hline \multirow[t]{2}{*}{ Soil sample } & \multirow[t]{2}{*}{ E.C. m.mohs/ $\mathrm{Cm}^{3}$} & \multirow[t]{2}{*}{ pH } & \multirow[t]{2}{*}{ Sp\% } & \multicolumn{3}{|c|}{ Anion (meq/L.) } & \multicolumn{4}{|c|}{ Cation (meq/L.) } \\
\hline & & & & $\mathrm{Hco}_{3}^{-}$ & $\mathrm{Cl}^{-}$ & $\mathrm{So}_{4}{ }^{--}$ & $\mathrm{Ca}^{++}$ & $\mathbf{M g}^{++}$ & $\mathrm{Na}^{++}$ & $\mathbf{K}^{+}$ \\
\hline Clay & 2.9 & 7.6 & 33.0 & 4.0 & 121.0 & 5.0 & 21.0 & 5.0 & 2.0 & 1.0 \\
\hline Sand & 2.1 & 7.1 & 23.0 & 2.0 & 23.0 & - & 4.0 & 3.0 & 15.0 & 5.0 \\
\hline
\end{tabular}

Table (C): Chemical analysis of peatmoss.

\begin{tabular}{|c|c|c|c|c|c|c|c|c|c|c|c|c|}
\hline \multirow{2}{*}{$\begin{array}{l}\text { Soil } \\
\text { sample }\end{array}$} & \multirow[t]{2}{*}{ Sp\% } & \multirow[t]{2}{*}{ pH } & \multirow[t]{2}{*}{ Ash\% } & \multirow{2}{*}{$\begin{array}{c}\text { Organic } \\
\text { matter }\end{array}$} & \multicolumn{8}{|c|}{ meq/L. } \\
\hline & & & & & N\% & $\mathbf{P \%}$ & K\% & $\mathrm{Ca} \%$ & Mg & $\mathrm{Fe}$ & Mn & $\mathbf{C u}$ \\
\hline Peat & $38 \%$ & $3.4-3.9$ & $1.2-2.2$ & 95- 98 & 3 & 0.03 & 2.1 & 1.9 & 2.7 & 17 & 4 & 1 \\
\hline
\end{tabular}

The experiment was set in a completely randomized design. The experiment had seven treatments. The treatment was replicated 3 times, and each replicate included 6 plants.

The available commercially fertilizer used through the two experimental work was kirstalon (NPK 19:19:19) produced by Phayzen company, Holand. The fertilizer rate was $3.0 \mathrm{~g} / \mathrm{pot}$, applied monthly after 30 days from transplanting.

\subsection{Data recorded}

2.2.1. On vegetative growth: Plant height $(\mathrm{cm})$ Stem diameter (cm)-Number of leaves/ plant Leaf area $\left(\mathrm{cm}^{2}\right)$-Fresh weight of leaves, stems, and roots (g)-Dry weight of leaves, stems, roots (g).

2.2.2. On chemical composition: The following chemical analyses were determined: total carbohydrate contents in leaves and stems (\% D.W) were determined according to the method

\section{RESULTS AND DISCUSSION 3.1. Vegetative growth 3.1.1. Plant height}

Data on plant height of Schefflera arboricola plants, as affected by the different growing media, are presented in Table (1).In the first season, the plants grown in peatmoss + clay medium $(2: 1)$ were the tallest $(77.00 \mathrm{~cm})$, whereas the shortest plants $(44.67 \mathrm{~cm})$ were recorded for plants grown in peatmoss + sand (2:1).Results of the second season, demonstrated that the plants growing in a mixture of peatmoss + clay $(2: 1)$ gave the tallest plant $(103.67 \mathrm{~cm})$, followed by the plants grown in a mixture of peatmoss+sand+ clay $(2: 1: 1)$ with $(95.33 \mathrm{~cm})$. The data revealed that adding clay to peatmoss or peatmoss + sand at any ratio increased plant height. On the other hand, using a growing medium containing sand without clay markedly decreased the plant height more than the other treatments. This may be due to the fact that clay 
soil had more nutrition elements than sandy soil. Similar trend was obtained by many investigators, El-Sallami and Makary (2001) on Thuja orientalis L., El-Khalifa (2003) on Dalbergia melanoxylon and Kathiravan et al. (2008) on Jatropha curcas.

\subsubsection{Stem diameter}

Data presented in Table (1) show the effect of different growing media on stem diameter of Schefflera arboricola plants.In the first season, the thickest diameter $(0.89 \mathrm{~cm})$ was recorded on plants grown in a mixture of peatmoss + clay $(2: 1)$, whereas the lowest value of stem diameter $(0.68 \mathrm{~cm})$ was found with the use of peatmoss + sand (1:1) as a growing media.

The results in the second season were similar to those obtained in the first one. The data showed that the plants grown in peatmoss + clay (2:1) or peatmoss + sand + clay (2:1:1) mixture gave the thickest stems $(1.24$ and $1.16 \mathrm{~cm}$, respectively). These findings are in agreement with those obtained by El-Sallami (2002) on Chorisia speciosa, Leucaena leucocephala, and Prosopis julifora.

\subsubsection{Number of leaves}

The results in Table (2) show that the number of leaves/ plant was significantly affected in response of the different growing media.
In the first season, the results also indicate that the growing media containing peatmoss + clay (2:1), peatmoss+ sand+ clay $(2: 1: 1)$ or peatmoss+ clay (1:1) significantly increased the number of leaves/ plant giving 28.00, 24.00 and 21.33 leaves/ plant, respectively, as compared with that obtained in the other growing media. The lowest value of the number of leaves/ plant (15.67) was recorded on plants grown in a mixture of peatmoss + sand $(2: 1)$.

In the second season, similar trend was observed. The average number of leaves/ plant ranged between 51.00 and 28.67. The highest value of number of leaves (51.00) was produced from peatmoss+ clay (2:1) medium, whereas the lowest value of number of leaves/ plant (28.67) was obtained from the mixture of peatmoss + sand $(1: 1)$.

These findings are in accordance with those reported by Azza et al. (2010) on Jatropha curca.

\subsubsection{Leaf area}

Leaf area in Schefflera plants was significantly affected in both seasons by growing media as shown in Table (2). Schefflera plants formed the largest leaves in the first season $\left(125.00 \mathrm{~cm}^{2}\right)$ when plants were grown in a mixture of peatmoss + clay (2:1), followed by the mixture of peatmoss + sand + clay $(2: 1: 1)$

Table (1): Effect of growing media on plant height, and stem diameter in Schefflera arboricola plant during 2007 and 2008 seasons.

\begin{tabular}{|ccccc|}
\hline \multirow{2}{*}{ Character } & \multicolumn{2}{c|}{ Plant height $(\mathbf{c m})$} & \multicolumn{2}{c|}{ Stem diameter (cm) } \\
\cline { 2 - 5 } Treatment & $\mathbf{1}^{\text {st }}$ season & $\mathbf{2}^{\text {nd }}$ season & $\mathbf{1}^{\text {st }}$ season & $\mathbf{2}^{\text {nd }}$ season \\
\hline Peatmoss & 50.00 & 76.70 & 0.76 & 0.94 \\
Peatmoss + sand (1:1) & 46.83 & 63.60 & 0.68 & 0.87 \\
Peatmoss + sand (2:1) & 44.67 & 68.40 & 0.72 & 0.91 \\
Peatmoss + clay (1:1) & 63.17 & 87.33 & 0.80 & 1.09 \\
Peatmoss + clay (2:1). & 77.00 & 103.67 & 0.89 & 1.24 \\
Peatmoss +sand + clay (1: 1: 1) & 55.83 & 83.60 & 0.80 & 1.03 \\
Peatmoss + sand+ clay (2: 1: 1) & 47.67 & 95.33 & 0.84 & 1.16 \\
\hline L.S.D at 5\% & $\mathbf{2 . 5 0}$ & $\mathbf{6 . 4 0}$ & $\mathbf{0 . 0 3}$ & $\mathbf{0 . 0 5}$ \\
\hline
\end{tabular}

Table (2): Effect of growing media on Number of leaves, and Leaf area in Schefflera arboricola plant during 2007 and 2008 seasons.

\begin{tabular}{|c|c|c|c|c|}
\hline \multirow[b]{2}{*}{ Treatment } & \multicolumn{2}{|c|}{ Number of Leaves } & \multicolumn{2}{|c|}{ Leaf area $\left(\mathrm{cm}^{2}\right)$} \\
\hline & $\mathbf{1}^{s t}$ season & $2^{\text {nd }}$ season & $\mathbf{1}^{s t}$ season & $2^{\text {nd }}$ season \\
\hline Peatmoss & 18.67 & 35.00 & 87.85 & 146.32 \\
\hline Peatmoss + sand $(1: 1)$ & 17.67 & 28.67 & 54.80 & 128.40 \\
\hline Peatmoss + sand (2:1) & 15.67 & 33.67 & 76.30 & 135.80 \\
\hline Peatmoss + clay $(1: 1)$ & 21.33 & 42.67 & 109.50 & 163.30 \\
\hline Peatmoss + clay $(2: 1)$. & 28.00 & 51.00 & 125.00 & 177.00 \\
\hline Peatmoss +sand + clay $(1: 1: 1)$ & 19.33 & 35.67 & 97.50 & 155.60 \\
\hline Peatmoss + sand+ clay $(2: 1: 1)$ & 24.00 & 49.67 & 119.90 & 172.00 \\
\hline L.S.D at $5 \%$ & $\mathbf{1 . 7 0}$ & 3.60 & 6.60 & 7.40 \\
\hline
\end{tabular}


$\left(119.90 \mathrm{~cm}^{2}\right)$ and peatmoss + clay (1:1) $(109.50$ $\left.\mathrm{cm}^{2}\right)$. Also, the smallest leaves were obtained with the mixture of peatmoss + sand (1:1) $\left(54.80 \mathrm{~cm}^{2}\right)$, followed by the mixture of peatmoss + sand $(2: 1)\left(76.30 \mathrm{~cm}^{2}\right)$.

In the second season, the plants grown in a mixture of peatmoss + clay $(2: 1)$, followed by the mixture of peatmoss + sand + clay $(2: 1: 1)$ and peatmoss + clay (1:1) produced the largest leaves $\left(177.00, \quad 172.00\right.$ and $163.30 \mathrm{~cm}^{2}$ respectively), compared with the other growing media. The mixture of peatmoss + sand (1:1) reduced the leaf area to $\left(128.40 \mathrm{~cm}^{2}\right)$, compared with the other growing media. The leaf area was markedly depressed with the use of sand as a mixture of growing media.

These results are in agreement with the results obtained by El-Khateeb et al. (2006) on Ficus alii.

\subsubsection{Fresh and dry weights of leaves}

Regarding the effect of the growing media on the fresh and dry weights of leaves, the data in Table (3), indicate that in the first and second seasons the fresh weight of leaves was significantly increased in the plants grown in the following mixtures: peatmoss+clay $(2: 1)$ was (101.70 and 161.72gm, respectively ), peatmoss+ sand+ clay (2:1:1) was (97.50 and $149.23 \mathrm{gm}$, respectively) and peatmoss+clay (1:1) was (84.67 and $139.83 \mathrm{gm}$, respectively).

Concerning the effect of the growing media on the dry weight of leaves in Table (4), the responses of dry weights of leaves of Schefflera arboricola plants to the growing media had almost the same trend of fresh weight, where using the mixtures of peatmoss +clay (2:1), peatmoss + sand +clay $(2: 1: 1)$ and peatmoss + clay (1:1) as growing media were favorable for producing the heaviest dry weight of leaves $(29.79,28.27$ and $24.21 \mathrm{~g})$ in the first season, and $(47.54,43.12$ and $39.85 \mathrm{~g})$ in the second, respectively. These results are in a harmony with El-Khateeb et al. (2006) on Ficus alii, Watfa (2009) on Ceratonia silique L. and Azza et al. (2010) on Jatropha curcas plants.

\subsubsection{Fresh and dry weights of stems}

As shown in Table (3), in both seasons, there were significant differences in fresh weight of stems of Schefflera arboricola plants. It was evident that using the mixture of peatmoss + clay (2:1) and peatmoss + sand + clay (2:1:1) had a favorable effect in increasing the fresh weight of stems in both seasons (31.33 and $30.76 \mathrm{~g}$, respectively) for the first season, (63.72 and $54.22 \mathrm{~g}$ ) for the second one, respectively. On the other hand, the mixtures of peatmoss + sand
$(1: 1)$ or peatmoss + sand $(2: 1)$ reduced the fresh weight of the stems to the minimum values in the first and second seasons.

Concerning the effect of the growing media on the dry weight of stems in both seasons as shown in Table (4), the dry weight of stems was the heaviest when the plants were grown in a mixture containing peatmoss + clay (2:1), followed by the mixtures of peatmoss + sand + clay $(2: 1: 1)$ and peatmoss + clay (1:1). Whereas, growing the plants in mixtures of peatmoss + sand $(1: 1)$ or peatmoss + sand $(2: 1)$ reduced the dry weight of stems, in both seasons, to the minimum values, compared with the other growing media. These results are in agreement with El-Sallami (1996) on Ficus benjamina plants and Azza et al. (2010) on Jatropha curcas plants.

\subsubsection{Fresh and dry weights of roots}

The effects of the growing media on the fresh and dry weights of roots are shown in Tables (3 and 4). It is clear from the data of the first and second seasons that the fresh weight of roots of the Schefflera arboricola plants was markedly increased when plants were grown in the mixture of peatmoss + clay (2:1) gave (22.28 and $43.84 \mathrm{gm}$, respectively), peatmoss + sand + clay $(2: 1: 1)$ gave $(20.18$ and $38.72 \mathrm{gm}$, respectively) and peatmoss + clay (1:1) gave (16.80 and $31.19 \mathrm{gm}$, respectively).

Regarding the effect of the growing media on dry weight of roots, it is clear from the data of the first and second seasons that the dry weight of roots of the Schefflera arboricola plants was markedly increased when the plants were grown in the following mixtures, peatmoss + clay $(2: 1)$ giving (7.80 and $15.26 \mathrm{gm}$, respectively), peatmoss + sand + clay $(2: 1: 1)$ giving (7.00 and $13.40 \mathrm{gm}$, respectively) and peatmoss + clay (1:1) giving the values of (5.76 and $10.67 \mathrm{gm}$, respectively). Using the mixture of peatmoss + sand (1:1) as a growing medium markedly reduced the dry weights of roots in both seasons to $(3.19$ and $5.15 \mathrm{gm})$, respectively. These results are in agreement with El-Khateeb et al. (2006) on two cultivars of Ficus alii and Azza et al. (2010) on Jatropha curcas L.

\subsection{Chemical constituents}

\subsubsection{Pigment contents}

The data in Table (5) show the effect of growing media on the contents of chlorophyll-a, $\mathrm{b}$ and carotenoids in the leaves of Schefflera arboricola plants. The results reveal that, the mixtures of peatmoss + clay (2:1) showed the highest content of chlorophyll-a (1.65 and 1.69 $\mathrm{mg} / \mathrm{gm} \mathrm{F.W})$ and chlorophyll-b (0.54 and 0.57 
Table (3): Effect of growing media on fresh weight of Schefflera arboricola leaves, stems and roots during 2007 and 2008 seasons

\begin{tabular}{|c|c|c|c|c|c|c|}
\hline \multirow{2}{*}{$\begin{array}{l}\text { Character } \\
\text { Treatment }\end{array}$} & \multicolumn{2}{|c|}{ Leaves fresh weight (g) } & \multicolumn{2}{|c|}{ Stem fresh weight $(\mathrm{g})$} & \multicolumn{2}{|c|}{ Root fresh weight (g) } \\
\hline & $1^{\text {st }}$ season & $2^{\text {nd }}$ season & $1^{\text {st }}$ season & $2^{\text {nd }}$ season & $\mathbf{1}^{s t}$ season & $2^{\text {nd }}$ season \\
\hline Peatmoss & 57.67 & 116.92 & 20.53 & 35.94 & 12.23 & 21.06 \\
\hline $\begin{array}{c}\text { peatmoss + sand } \\
(1: 1)\end{array}$ & 50.70 & 96.21 & 15.36 & 26.30 & 9.75 & 15.80 \\
\hline $\begin{array}{c}\text { peat moss+ sand } \\
(2: 1)\end{array}$ & 52.30 & 107.20 & 18.70 & 32.39 & 11.45 & 18.72 \\
\hline $\begin{array}{c}\text { peat moss+ clay } \\
(1: 1)\end{array}$ & 84.67 & 139.83 & 27.14 & 51.70 & 16.80 & 31.19 \\
\hline $\begin{array}{c}\text { peatmoss + clay } \\
(2: 1) .\end{array}$ & 101.70 & 161.72 & 31.33 & 63.72 & 22.28 & 43.84 \\
\hline $\begin{array}{l}\text { peatmoss }+ \text { sand }+ \\
\text { clay }(1: 1: 1)\end{array}$ & 69.33 & 125.45 & 23.64 & 43.29 & 14.90 & 25.17 \\
\hline $\begin{array}{l}\text { peatmoss }+ \text { sand }+ \\
\text { clay }(2: 1: 1)\end{array}$ & 97.50 & 149.23 & 30.76 & 54.22 & 20.18 & 38.72 \\
\hline L.S.D at $5 \%$ & 10.2 & 8.3 & 2.9 & 5.7 & 1.6 & 4.0 \\
\hline
\end{tabular}

Table (4): Effect of growing media on dry weight of Schefflera arboricola leaves, stems and roots during 2007 and 2008 seasons

\begin{tabular}{|c|c|c|c|c|c|c|}
\hline \multirow{2}{*}{$\begin{array}{l}\text { Character } \\
\text { Treatment }\end{array}$} & \multicolumn{2}{|c|}{ Leaves dry weight (g) } & \multicolumn{2}{|c|}{ Stem dry weight (g) } & \multicolumn{2}{|c|}{ Root dry weight (g) } \\
\hline & $\mathbf{1}^{\text {st }}$ season & $2^{\text {nd }}$ season & $1^{s t}$ season & $2^{\text {nd }}$ season & $\mathbf{1}^{s t}$ season & $2^{\text {nd }}$ season \\
\hline Peatmoss & 15.97 & 32.26 & 6.20 & 10.82 & 4.11 & 7.05 \\
\hline $\begin{array}{c}\text { peatmoss + sand } \\
(1: 1)\end{array}$ & 13.58 & 25.68 & 4.53 & 7.73 & 3.19 & 5.15 \\
\hline $\begin{array}{c}\text { peatmoss + sand } \\
(2: 1)\end{array}$ & 14.23 & 29.05 & 5.59 & 9.65 & 3.79 & 6.55 \\
\hline $\begin{array}{c}\text { peatmoss + clay } \\
(1: 1)\end{array}$ & 24.21 & 39.85 & 8.41 & 15.95 & 5.76 & 10.67 \\
\hline $\begin{array}{c}\text { peatmoss + clay } \\
(2: 1) .\end{array}$ & 29.79 & 47.54 & 10.02 & 20.33 & 7.80 & 15.26 \\
\hline $\begin{array}{c}\text { peatmoss }+ \text { sand }+ \\
\text { clay }(1: 1: 1)\end{array}$ & 19.48 & 35.12 & 7.26 & 13.31 & 5.07 & 8.53 \\
\hline $\begin{array}{l}\text { Peatmoss }+ \text { sand }+ \\
\text { clay }(2: 1: 1)\end{array}$ & 28.27 & 43.12 & 9.69 & 17.17 & 7.00 & 13.40 \\
\hline L.S.D at $5 \%$ & 2.2 & 3.1 & 1.3 & 2.5 & 0.4 & 1.2 \\
\hline
\end{tabular}

Table (5): Effect of growing media on chlorophyll a, b, and carotenoids in leaves of Schefflera arboricola during 2007 and 2008 seasons

\begin{tabular}{|c|c|c|c|c|c|c|}
\hline \multirow{2}{*}{$\begin{array}{l}\text { Character } \\
\text { Treatment }\end{array}$} & \multicolumn{2}{|c|}{ Chlorophyll a (mg/gF.W.) } & \multicolumn{2}{|c|}{ Chlorophyll b (mg/gF.W.) } & \multicolumn{2}{|c|}{ Carotenoids (mg/g F.W.) } \\
\hline & $\mathbf{1}^{s t}$ season & $2^{\text {nd }}$ season & $\mathbf{1}^{s t}$ season & $2^{\text {nd }}$ season & $\mathbf{1}^{s t}$ season & $2^{\text {nd }}$ season \\
\hline Peatmoss. & 1.55 & 1.58 & 0.44 & 0.45 & 0.23 & 0.24 \\
\hline $\begin{array}{c}\text { peatmoss + sand } \\
(1: 1)\end{array}$ & 1.51 & 1.54 & 0.40 & 0.41 & 0.20 & 0.20 \\
\hline $\begin{array}{c}\text { peatmoss + sand } \\
(2: 1)\end{array}$ & 1.52 & 1.56 & 0.41 & 0.44 & 0.21 & 0.22 \\
\hline $\begin{array}{c}\text { peatmoss + clay } \\
(1: 1)\end{array}$ & 1.60 & 1.64 & 0.49 & 0.52 & 0.27 & 0.29 \\
\hline $\begin{array}{c}\text { peatmoss + clay } \\
(2: 1)\end{array}$ & 1.65 & 1.69 & 0.54 & 0.57 & 0.31 & 0.35 \\
\hline $\begin{array}{c}\text { peatmoss }+ \text { sand }+ \\
\text { clay }(1: 1: 1)\end{array}$ & 1.57 & 1.61 & 0.48 & 0.49 & 0.26 & 0.27 \\
\hline $\begin{array}{l}\text { peatmoss }+ \text { sand+ } \\
\text { clay }(2: 1: 1)\end{array}$ & 1.62 & 1.66 & 0.52 & 0.54 & 0.30 & 0.32 \\
\hline L.S.D & 0.020 & 0.020 & 0.018 & 0.027 & 0.013 & 0.019 \\
\hline
\end{tabular}


$\mathrm{mg} / \mathrm{gm}$ F.W) in the leaves in the first and second seasons, respectively. The lowest contents of chlorophyll-a in the first and second seasons were (1.51 and $1.54 \mathrm{mg} / \mathrm{gm} \mathrm{F.W}$ ), respectively in the Leaves. This was recorded when the plants were grown in peatmoss + sand (1:1).The lowest contents of chlorophyll-b in both seasons were recorded when the plants were grown in peatmoss + sand $(1: 1)$ and peatmoss + sand (2:1). Concerning the effect of media on the content of carotenoids, the obtained data, indicate that the highest values of the carotenoids $(0.31$ and $0.30 \mathrm{mg} / \mathrm{gm} \mathrm{F} . W$.$) in the leaves in the$ first season and were $(0.35$ and $0.32 \mathrm{mg} / \mathrm{gm}$ F.W.) in the leaves in the second one. These were recorded with the mixture of peatmoss + clay $(2: 1)$ and peatmoss + sand+ clay (2:1:1), respectively. The lowest values of the carotenoids were $(0.20$ and $0.21 \mathrm{mg} / \mathrm{gm}$ F.W. $)$ in the first season and were $(0.20$ and $0.22 \mathrm{mg} / \mathrm{gm}$ F.W.) in the second one. These were recorded with the mixture of peatmoss + sand (1:1) followed by the mixture peatmoss + sand $(2: 1)$, respectively. In this concern, El-Khateeb (1983) on Eucalyptus torquata found that plants grown in mixture of clay + peatmoss had a high chlorophyll content. Whereas, Farahat (1986) found that Eucalyptus camaldulensis seedlings grown in a mixture of sand + peatmoss contained more chlorophyll-a in the leaves, whereas a mixture of clay + peatmoss gave a higher content of chlorophyll-b. The seedlings grown in sandy soil had the lowest carotenoid content than the other media.

\subsubsection{Total Carbohydrates (\%D.W.)}

The data in Table (6) show the effect of growing media on the content of carbohydrates in the different parts of Schefflera arboricola plant. The results showed that, in both seasons growing Schefflera plants in peatmoss+ clay $(2: 1)$, peatmoss+ sand+ clay $(2: 1: 1)$ markedly increased the content of carbohydrates in the leaves. The highest values of the carbohydrate contents in the leaves were $(26.60 \%$ and $27.40 \%$ in the first and second seasons, respectively). These were recorded with the mixture of peatmoss + clay $(2: 1)$, whereas the lowest one in the leaves $(13.90 \%$ and $16.50 \%$ in the first and second seasons, respectively) were recorded when plants were grown in peatmoss+ sand $(2: 1)$.

The stem content of carbohydrates reached the highest value when the plants were grown in peatmoss + clay (2:1) in both seasons, giving $(21.20 \%$ and $24.20 \%$ D.W. $)$ in the first and second seasons, respectively. On the other hand, the lowest value of carbohydrate content was recorded when the plants grown in the mixture of peatmoss + sand $(2: 1)$.

In this connection, El-Sallami (1996) on Ficus benjamina, found that media composed of peatmoss + clay produced high leaf contents of carbohydrates. Also, Saleh (2000) on Ficus benjamina cv. "Starlight" indicated that peatmoss+ sand+ clay mixture resulted in the highest total content of carbohydrates

\subsubsection{Nutrient contents}

\subsubsection{Nitrogen content}

In the first and second seasons, the data in Table (7) indicate that the nitrogen percentage increased in the leaves of plants grown in a mixture of peatmoss + clay (2:1) giving (2.25 and $2.44 \%$ D.W., respectively).Also the highest value of nitrogen percentage in the stem (1.96 and $2.16 \%$ D.W., respectively) was obtained from plants grown in peatmoss + clay ( 2:1) in both seasons. In the first season, using a mixture of peatmoss + sand (2:1) resulted in the lowest $\mathrm{N}$ percentage $(1.60 \%)$, but in the second season a mixture of peatmoss + sand $(2: 1$ or $1: 1)$ as growing media for Schefflera plants resulted in the lowest $\mathrm{N}$ values (1.95 and 1.98\% D.W., respectively). In this regard, Saleh (2000) on Ficus benjamina cv. "Starlight" indicated that peatmoss + sand + clay mixture resulted in higher content of $\mathrm{N}$.

\subsubsection{Phosphorus content}

Data presented in Table (7) show the effect of different growing media on $\mathrm{P}$ content in Schefflera plants. In the first and second seasons the peatmoss with clay (a.i. peatmoss + clay $(2: 1)$, peatmoss + clay + sand $(2: 1: 1)$ and peatmoss + clay (1:1)) gave the highest value of $\mathrm{P}$ content in the leaves $(0.53,0.47$ and $0.42 \%$ D.W., respectively) in the first season and (0.62, 0.60 and $0.56 \%$ D.W., respectively) in the second season. The lowest values of $\mathrm{P}$ content $(0.26$ and $0.29 \%$ D.W., respectively) were recorded in the first season and $(0.40 \%$ and $0.44 \%$ D.W., respectively) in the second season produced with the addition of sand to peatmoss (a.i. peatmoss + sand $(2: 1)$ and peatmoss + sand (1:1)). In the stems the results indicate that, the highest content of $\mathrm{P}$ percentage in the first and second seasons (0.45 and $0.47 \%$ D.W., respectively) was recorded from plants grown in peatmoss + clay (2:1), but the lowest value in both seasons $(0.27$ and $0.32 \%$ D.W., respectively) resulted from plants grown in peatmoss + sand (2:1).

\subsubsection{Potassium content}

The results concerning the effect of different growing media on potassium content of the 
leaves for S. arboricola plants are presented in Table (8). In the first season ,the potassium content in leaves of plants grown in a mixture of peatmoss + clay (2:1) gave the highest value of K content (1.26\% D.W.), Peatmoss + sand (1:1) and peatmoss + sand (2:1) gave the lowest content of $\mathrm{K}$ in leaves ( 1.12 and $1.13 \%$ D.W., respectively) compared with the other media. In the second season, the highest Percentage of $\mathrm{K}$ in leaves $(1.30 \%$ D.W.) was recorded from plants grown in a mixture of peatmoss + clay (2:1). On the other hand, using a mixture of peatmoss + sand (1:1) resulted in the lowest $\mathrm{K}$ percentage (1.16\% D.W.).

Table (6): Effect of growing media on total carbohydrates in Schefflera arboricola leaves and stems during 2007 and 2008 seasons

\begin{tabular}{|lcccc|}
\hline \multirow{2}{*}{ Treatment } & Character & $\begin{array}{c}\text { Carbohydrates of Leaves } \\
\text { \%D.W. }\end{array}$ & \multicolumn{2}{c|}{$\begin{array}{c}\text { Carbohydrates of Stems \%. } \\
\text { D.W. }\end{array}$} \\
& & & & \\
\cline { 2 - 5 } & $\mathbf{1}^{\text {st }}$ season & $\mathbf{2}^{\text {nd }}$ season & $\mathbf{1}^{\text {st }}$ season & $\mathbf{2}^{\text {nd }}$ season \\
\hline Peatmoss & 17.40 & 19.50 & 14.30 & 16.53 \\
Peatmoss + sand (1:1) & 15.20 & 18.70 & 12.50 & 15.60 \\
Peatmoss + sand (2:1) & 13.90 & 16.50 & 11.20 & 13.50 \\
Peatmoss + clay (1:1) & 20.40 & 24.10 & 18.80 & 21.60 \\
Peatmoss + clay (2:1). & 26.60 & 27.40 & 21.20 & 24.20 \\
Peatmoss +sand + clay (1: 1: 1) & 20.10 & 21.20 & 16.70 & 19.80 \\
Peatmoss + sand+ clay (2: 1: 1) & 22.80 & 25.36 & 20.83 & 22.50 \\
\hline L.S.D at 5\% & $\mathbf{1 . 9 0}$ & $\mathbf{1 . 6 8}$ & $\mathbf{1 . 2 2}$ & $\mathbf{1 . 6 2}$ \\
\hline
\end{tabular}

Table (7): Effect of growing media on Nitrogen and Phosphorus (\% D.W.) of leaves and stems of Schefflera arboricola during 2007and 2008 seasons.

\begin{tabular}{|c|c|c|c|c|c|c|c|c|}
\hline \multirow[b]{2}{*}{ Treatment } & \multicolumn{2}{|c|}{$\begin{array}{l}\text { Nitrogen of } \\
\text { Leaves }\end{array}$} & \multicolumn{2}{|c|}{$\begin{array}{l}\text { Nitrogen of } \\
\text { Stems }\end{array}$} & \multicolumn{2}{|c|}{$\begin{array}{c}\text { Phosphorus of } \\
\text { Leaves }\end{array}$} & \multicolumn{2}{|c|}{$\begin{array}{c}\text { Phosphorus of } \\
\text { Stems }\end{array}$} \\
\hline & $\begin{array}{c}\mathbf{1}^{\text {st }} \\
\text { season }\end{array}$ & $\begin{array}{c}2^{\text {nd }} \\
\text { season }\end{array}$ & $\begin{array}{c}1^{\text {st }} \\
\text { season }\end{array}$ & $\begin{array}{c}2^{\text {nd }} \\
\text { season }\end{array}$ & $\begin{array}{c}1^{\text {st }} \\
\text { season }\end{array}$ & $\begin{array}{c}2^{\text {nd }} \\
\text { season }\end{array}$ & $\begin{array}{c}\mathbf{1}^{\text {st }} \\
\text { season }\end{array}$ & $\begin{array}{c}2^{\text {nd }} \\
\text { season }\end{array}$ \\
\hline $\begin{array}{c}\text { Peatmoss. } \\
\text { peatmoss + sand }\end{array}$ & 2.10 & 2.27 & 1.71 & 2.03 & 0.34 & 0.48 & 0.32 & 0.36 \\
\hline $\begin{array}{c}(1: 1) \\
\text { peatmoss + sand }\end{array}$ & 2.06 & 2.22 & 1.67 & 1.98 & 0.29 & 0.44 & 0.29 & 0.30 \\
\hline $\begin{array}{c}(2: 1) \\
\text { peatmoss + clay }\end{array}$ & 2.00 & 2.18 & 1.60 & 1.95 & 0.26 & 0.40 & 0.27 & 0.32 \\
\hline $\begin{array}{c}(1: 1) \\
\text { peatmoss + clay }\end{array}$ & 2.17 & 2.36 & 1.82 & 2.08 & 0.42 & 0.56 & 0.38 & 0.41 \\
\hline $\begin{array}{c}(2: 1) \\
\text { peatmoss +sand + }\end{array}$ & 2.25 & 2.44 & 1.96 & 2.16 & 0.53 & 0.62 & 0.45 & 0.47 \\
\hline $\begin{array}{c}\text { clay }(1: 1: 1) \\
\text { peatmoss + sand+ }\end{array}$ & 2.15 & 2.31 & 1.77 & 2.06 & 0.38 & 0.52 & 0.34 & 0.38 \\
\hline clay $(2: 1: 1)$ & 2.21 & 2.40 & 1.88 & 2.12 & 0.47 & 0.60 & 0.41 & 0.43 \\
\hline L.S.D. at $5 \%$ & 0.03 & 0.02 & 0.03 & 0.02 & 0.03 & 0.03 & 0.01 & 0.01 \\
\hline
\end{tabular}

Table (8): Effect of growing media on Potassium (\%D.W.) of Schefflera arboricola Leaves and stems during 2007 and 2008 seasons.

\begin{tabular}{|c|c|c|c|c|}
\hline \multirow{2}{*}{ Character } & \multicolumn{2}{|c|}{ Potassium of Leaves } & \multicolumn{2}{|c|}{ Potassium of Stems } \\
\hline & $\mathbf{1}^{s t}$ season & $2^{\text {nd }}$ season & $\mathbf{1}^{\text {st }}$ season & $2^{\text {nd }}$ season \\
\hline \multicolumn{5}{|l|}{ Treatment } \\
\hline Peatmoss & 1.16 & 1.20 & 1.02 & 1.05 \\
\hline Peatmoss + sand $(1: 1)$ & 1.12 & 1.16 & 0.98 & 1.00 \\
\hline Peatmoss + sand (2:1) & 1.13 & 1.17 & 1.00 & 1.03 \\
\hline Peatmoss + clay $(1: 1)$ & 1.21 & 1.26 & 1.10 & 1.12 \\
\hline Peatmoss + clay $(2: 1)$ & 1.26 & 1.30 & 1.15 & 1.17 \\
\hline Peatmoss +sand + clay $(1: 1: 1)$ & 1.18 & 1.22 & 1.06 & 1.08 \\
\hline Peatmoss + sand+ clay $(2: 1: 1)$ & 1.24 & 1.27 & 1.14 & 1.15 \\
\hline L.S.D at $5 \%$ & $\mathbf{0 . 0 1}$ & $\mathbf{0 . 0 1}$ & $\mathbf{0 . 0 2}$ & $\mathbf{0 . 0 2}$ \\
\hline
\end{tabular}


In the first season, the $\mathrm{K}$ content of stems ranged from 0.98 to $1.14 \%$ D.W., for plants grown in a mixture of peatmoss + clay (2:1). These gave the highest values of $\mathrm{K}$ percentage (1.15 and $1.17 \%$ D.W. respectively) in the two seasons. On the other hand the lowest values of $\mathrm{K}$ percentage in the first and second seasons (0.98 and $1.00 \%$ D.W, respectively) were obtained from plants grown in peatmoss+ sand (1:1). In this connection, Saleh (2000) on Ficus benjamina "Starlight" grew plants in different planting media, and indicated that peatmoss+ sand+ clay mixture resulted in high $\mathrm{K}$ content.

\section{REFERENCES}

Chapman H.D. and Pratt P.F. (1961). Methods of Analysis for Soils, Plant and Water. Div. of Agric. Sci., Univ. of Calif., USA, pp: 309

Cottenie A., Verloo M., Kiekens L., Velghe G. and Camerlynck R. (1982). Chemical Analysis of Plant and Soil Laboratory of Anolytical and Agrochemistry, State Univ. Ghent. Belgium, pp: 100-129.

Dubois M., Smisth F., Gilles K.A., Hamilton J.K. and Rebers P.A. (1956). Colorimetric method for determination of sugars and related substances. Anal. Chem., 28: 350356.

El-Afghani S. A. (1981). Effect of soil mixtures and NPK fertilization on the growth of Eucalyptus camaldulensis and Cupressus sempervirens transplants in the nursery. M.Sc. Thesis, Fac. Agric., Al-Fateh Univ., Triopli, Libya

El-Fouly A. S. (1994). Physiological studies on Peperomia obtustifolia,L. and Scindapsus aureus Schott plants, M. Sc. Thesis, Fac. Of Agric. Cairo Univ., Egypt. 193p.

El-Khalifa K. F. (2003). Nursery establishment of abanus (Dalbergia melanoxylon Guill. And Perr.) Arab Gulf Journal of Scientific Research.21(3):153-157.

El-Khateeb M.A. (1983). Effect of salinity, irrigation, chemical fertilization and soil media on growth, flowering, chemical composition and essential oil of Eucalyptus torqulata and Eucalyptus angulosa. Ph.D. Thesis, Fac. of Agric., Cairo Univ., Egypt. $349 \mathrm{p}$.

El-Khateeb M. A., El-Maadawy E. I. and ElAtter A. A. (2006). Effect of growing media on growth and chemical composition of Ficus alii. Plants. Annals of Agricultural Science, Moshtohor, 46 (2): 1987-1998.

El- Sallami I. H. (1996). Response of Ficus benjamina $\mathrm{L}$. to different potting media and doses of nutrient solution. Assiut J. Agric. Sci., 27(3): $61-76$.

El-Sallami I. H.(2002). Seedling response of some ornamental trees to soil type and NPK fertilization. Assiut Journal of Agricultural Science, 33 (3): $49-83$.

El-Sallami I. H. and Makary B. Sh. (2001). Growth and chemical composition of Thuja orientalis L. seedlings as affected by saline irrigation water, soil moisture content and soil type. Assiut Journal of Agriculture Science, 32 (3):61-86.

El- Shoura H. A. S. and Hosni A. M. (1996). Growing Strelitzia reginae, in improved sandy growing media under different levels of fertilization. Annals Agri. Sci. Cairo, 41 (2): $973-991$.

El- Tantawy A. (1981). Effect of chemical fertilization, soil media and gibberellic acid on growth of some tree seedlings. M.Sc. Thesis, Fac. Agric., Cairo Univ., Egypt. 100 p.

Farahat M. M. (1986). Some studies on Eucalyptus camaldulensis, Dehn. M. Sc. Thesis, Fac. Agric., Cairo Univ., Egypt. 160 p.

Kathiravan M., Ponnuswamy A.S. and Vanitha C. (2008). Influence of soil types on seedlings production in Jatropha (Jatropha curcas L.) Plant Archives, 8(1): 111-113.

Mazhar A. A. M., Abd El Aziz N. G. A. and Habba E. E. (2010). Impact of different soil media on growth and chemical constituents of Jatropha curca L.seedlings grown under water regime. Journal of American Science. 6(8): 549-556.

Osman H. H. (2002). Effect of some growth regulators, pinching and some growing media on growth and chemical composition of Nerium oleander L. plants. Ph. D. Thesis, Fac. Agric., Cairo Univ., Egypt. 205p.

Saleh S. I. (2000). Effect of different planting media on the growth and chemical composition of Ficus benjamina "Starlight" plants grown under two locations "outdoor and plastic house" conditions. Egypt J. Hort; 27 (4): 543-568.

Saleh S. I. I. (2001). Effect of planting media on germination of Cycas revoluta, Thumb seeds. Egypt. J. Hort; 28 (2): 159 - 169.

Saric M., Kostrori R., Guppina T. and Geris I. (1967). Chlorophyll determination Univ. U. Noven Sadu Prakitikum is kiziologize Bilijaka- Beogard, Haucana, Anjiga, pp: 215.

Snedecor G. W. and Cochran W.G. (1980). Statistical Methods. $6^{\text {th }}$ ed. Iowa State Univ., 
Press, Ames, lowa, USA. p 953.

Watfa R. A. (2009). Effect of Soil Media, Nutrition and Mycorrhiza Fungi on Chemical
Composition of Carob and Aleppo pine Seelings. M. Sc. Thesis, Fac. Agric., Cairo Univ., Egypt. 156p.

$$
\begin{aligned}
& \text { تأثير بيئات النمو المختلفة علي النمو والتركيب الكيماوي }
\end{aligned}
$$

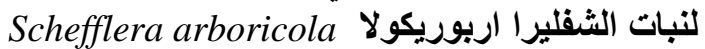

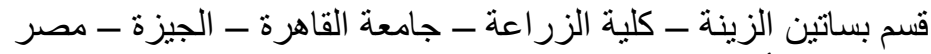

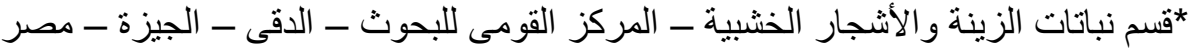

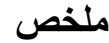

تم در اسة تأثير بيئات النمو المختلفة علي النمو والمكونات الكيميائية لنبات الثفلير ا اربوريكو لا خلال الموسمين

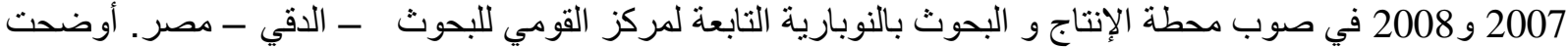
النتائج ان استخدام المخاليط المكونة من البيتموس + الطمي ( 2 (: 1:) و البيتموس + الرمل

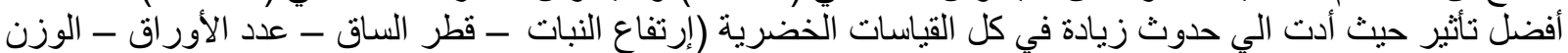

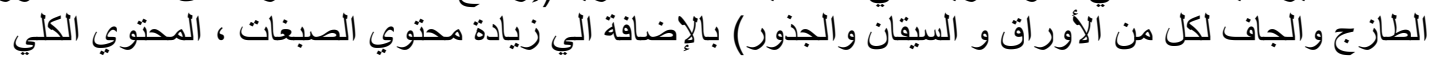

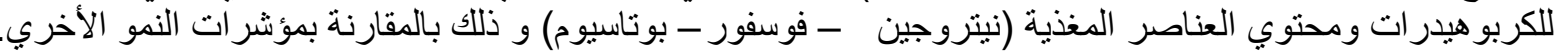

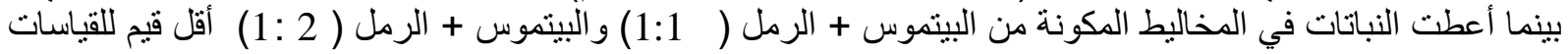

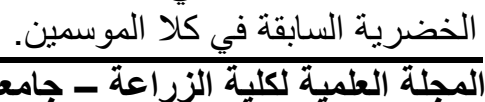

